\title{
THE DISCIPLINE IN THE MAKING: APPRAISING THE PROGRESS OF ISLAMIC ECONOMICS
}

\author{
Hafas Furqani ${ }^{1}$
}

\begin{abstract}
Islamic economics is currently moving from a mere discourse on economics in Islamic perspective towards becoming a distinct science of Islamic economics. There is a systematic effort from Islamic economic scientific community to develop a discipline of Islamic economics marked by a complete body of knowledge, clear subject matter, methodology/methodologies to appraise theories and continuous growth and accumulation of knowledge. This could be done if the scientific community put strong effort in explicating all the necessary foundations of science and achieve consensus on certain important aspect of discipline. In this paper we attempt to historically survey the development of Islamic economics towards becoming a distinct discipline, evaluate the current practices a adopted by the Islamic economics' scientific community in settling up problems, and outlining forward agenda in order to achieve this discipline status.
\end{abstract}

Keywords: Islamic economics, foundations, discipline, body of knowledge, development

JEL Classification: A19, B29, B49, B59

1 Author is lecturer at Department of Economics, Faculty of Islamic Economics and Business, UIN Ar-Raniry, Banda Aceh (hafasf@gmail.com). 


\section{INTRODUCTION}

Islamic economics is still in the process of development toward becoming a distinct discipline. Its scientific elements, body of knowledge, methodology, are still in process of development and will continuously evolve to a more mature and sophisticated level in the future, provided all dimensions, including its philosophical foundations are given sufficient attention.

As a systematic system of thought with an organized body of knowledge, Islamic economics is a twentieth century phenomenon. However, its process of development has been evolved back to the time when Islamic science flourished in the golden age of Islamic civilization especially in seventh to fourteenth century and has practical justification back to the time of Prophet Muhammad pbuh.

This paper is going to investigate the historical development of Islamic economics started from the early making of Islamic economics in the classical period until it becomes a distinct discipline in contemporary time. In our observation, the evolution of Islamic economic thought has been happened in three phases; Islamic economics in the classical discourse, Islamic economics in the transitional period and Islamic economics in contemporary time. This paper will proceed according to those phases with an insight of the future development of Islamic economics to be a distinct discipline.

\section{ISLAMIC ECONOMICS IN THE CLASSICAL DISCOURSE}

Economics is actually not a new discourse in Islamic scientific tradition. Earlier, Muslim scholars have actually dealt with economic problems. Economic issues, although may not be dominant, have occupied the minds of philosophers, jurists, sufis, etc., each responding in their own way. Economic thought in Islam can be seen as the Muslim scholars' response to the economic challenges of their times. On the other hand, the Islamic state, started from the era of the Prophet Muhammad S.A.W has put the Islamic principles of economics in practice. The Islamic thinkers at that time have analyzed the practices thoroughly and developed economic principles and theories. In this endeavour, they were aided and guided by the Qur'an and 
Sunnah as well as by intellectual reasoning and some fact observations.

However, we could wonder why a distinct economic discipline did not emerge in the Islamic golden era when Muslims dominated the world's scientific tradition meanwhile the economic problems were discussed extensively by Muslim scholars of that time ${ }^{2}$. A particular discipline of economics and a specifically Islamic science of economics with its systematic framework of study had not been developed in Islamic civilization but only later in the history of mankind. A standard textbook in the history of economic thought would probably refer to the ideas of the Mercantilists and Physiocrats of the $16^{\text {th }}$ and $17^{\text {th }}$ centuries and move on to Adam Smith who wrote his magnum opus "Inquiry into the Nature and Causes of the Wealth of Nations" (1776).

Some reasons might be put forward as explanations of this historical fact. First, there was no a great demand at that time, probably, for an independent and profound economic study due to the relatively simple and uncomplicated economic life. Economic analysis, perhaps, were adequately discussed in figh, philosophy or public policy (siyasah) framework. As a result, the discussions of economics at that time were not systematically independent. They were part of the numerous works of figh, tasawwuf and falsafah and consequently these discussions were merged in the works of fiqh, tasawwuf and falsafah. Apart from that, the scientific tradition then was dominated by 'revealed knowledge' represented by sciences such as 'ilm al-Qur'ān, 'ilm al-tafsir, 'ilm al-hadits, 'ilm al-fiqh, 'ilm al-kalam, etc. Other bodies of knowledge, dealing with 'economic' matters, while receiving some attentions by earlier Muslim scholars were not placed under a specific discourse or discipline to be studied ${ }^{3}$.

Second, some scholars such as Abu Yūsuf (d. 798), al-Mas ${ }^{\complement} \bar{u} d i$ (d. 957), al-Māwardi (d. 1058), Ibn Hazm (d. 1064), al-Sarakhsi (d.1090), al- Tūsi (d. 1093), al-Ghazāli (d. 1111), al-Dimashqi (d. after 1175), Ibn Rushd (d. 1198), Ibn Taymiyyah (d. 1328), Ibn al-

2 Alatas (2006: 590) for example writes "in the classical tradition, there were discussions and worls on economic thought, institutions and practices in the Muslim world, but the notion of an Islamic science of economics and a specifically Islamic economy did not exist. Islamic economics therefore a modern creation."

3 Aidit Ghazaly (1991) classified the group of early scholars that discussed economic issues into the jurist (fuqahā), the philosophers (ahl al-falsafah) and the ascetics/mystics (ahl al-tas\{awuf). Their thoughts on economics are usually mixed in the study of figh, falsafah or tas\{awwuf. 
Ukhuwwah (d. 1329), Ibn al-Qayyim (d. 1350), al-Shatibi (d. 1388), Ibn Khaldun (d. 1406), al-Maqrizi (d. 1442), and al-Dawwāni (d. 1501) had actually initiated discussions of various economic issues in their works. However there was no impetus to discuss 'economics' specifically in a strict compartmentalization of discipline by these scholars as well as the subsequent scholars. Economic thoughts, unfortunately, were left scattered in their works.

Third, the decline of Islamic civilization also contributed to the decline in scientific development in the Islamic world. Although there may have been a possibility to create disciplines such as economics, as seen in the magnificent work of Ibn Khaldun's al-Muqaddimah wrote in 1377, the decline of Islamic civilization had closed this opportunity ${ }^{4}$. The rise of Western civilization on the other hand gave the opportunity to western scholars to continue the advancement of knowledge developed in the Islamic world, leading to the establishment of the mercantilists, physiocrats and classical schools of thought which later on lead to the establishment of economics ${ }^{5}$.

However, we should realize that even though the specific economics discipline did not emerge in Islamic civilization, the economic thought of Muslim scholars was a 'living' fact. Several historical surveys of Islamic economic thought such as Bernard Lewis (1970), M. N. Siddiqi (1981), Volker Nienhaus (1982), Sabri Orman (1997), S. M. Ghazanfar (2003) and Abdul Azim Islahi (2004) found that there was no particular age that was devoid of Muslim scholars' views on economics, even at the time of the golden era of capitalist economics ( $19^{\text {th }}$ century).

Muslim scholars have produced original ideas of economic thought that are derived from scholars' intellectual contemplation of

4 A. A. Islahi (1995: 9) when he discusses the view of earlier Muslim scholars on market mechanism in Islam acknowledges this by saying "unfortunately, Ibn Taymiyah and Ibn Khaldun were born on the eve of a decline in Muslim sciences and culture. Therefore, the theory expounded by them could not be improved upon to any degree".

5 Sadeq (44) describes this unfortunate phenomena in the history of Muslim civilization as follows: "this process of research in the area of Islamic economics, as a response to the needs of the time, continued as in the other branches of science and knowledge, but with the downfall of the Muslim era the tradition became weak and stopped when the Muslim lost their position in knowledge, science and technology as a result of colonialization and deliberate conspiracy of colonial powers. Then Muslims, could not any more keep pace with the needs of the time, which was taken over by the colonial masters. Economics started taking shape as a formal discipline from the time of Adam Smith and reached the stage where it is now." 
the economic realities at that time and from the insights derived from the Qur'an and Sunnah as can be seen clearly in their works. Those initial discussions in the Islamic history were essentially the origins of economic thought in Islam and are the roots for contemporary Islamic economics development.

Currently, many researches have been done to investigate those roots of the history of Islamic economics thought. The goal of the research is not only to proof that there was no of what Schumpeter claimed as the "dark age" in the medieval age of the world history where there was no significant discussion of economic thought in human history, but also to investigate the historical continuity of ideas in the Muslim scientific tradition while gaining insights on the practical system of economy in the history of Islamic civilization.

\section{ISLAMIC ECONOMICS IN THE TRANSITIONAL PHASE}

European conquests of Muslim lands beginning in the $16^{\text {th }}$ century and $17^{\text {th }}, 18^{\text {th }}$ century, demonstrated the rise of Europe in world domination. On the hand, the Muslims civilization is slightly weakened and decline, slightly reduced its capability to creatively respond to the challenges. However, in this phase, although civilization was experiencing a decline, Muslims still able to maintain their 'Islamic identity', the thing that will be wiped out mostly (if not totally) in the time when Western colonialized the Muslim world in the $19^{\text {th }}$ century.

The decline of Islamic civilization implicated to the decline of dynamic research activities in Islamic world ${ }^{6}$. With the collapse of Ottoman Empire and massive expansion of Western colonialism, the

6 Scholars while agree on the phenomenon of a decline of Islamic civilization (science) in the world history, they have difference views on when the decline of Islamic science took place. David C. Lindberg (1992) for example states that Islamic science went into a decline during $13^{\text {th }}, 14^{\text {th }}$, and that by $15^{\text {th }}$ century little was left. Ahmad Y. al-Hassan (1996) on the other hand argues that while Islamic science maintained its leadership between $8^{\text {th }}$ and $12^{\text {th }}$ century, it also flourished between $13^{\text {th }}$ and $16^{\text {th }}$ centuries and maintained its lead. Aydin Sayili (1960) on the other hand rejects the notion of a 'general uniform' decline of Islamic science in the amount of knowledge in circulation or available for circulation in the Muslim world as commonly understood for three reasons: (1) Islamic empire covered a vast geographical area in which not all centres of scientific activity were in the same phase of development at the same time; (2) decline in one branch may coincide with progress in another; (3) much specific research is needed before reliable general conclusions are made. For more discussion on the theory of decline of Islamic science after $11^{\text {th }}$ century read Mohammad Abdalla (2007). 
focus of Muslim scholars was no longer to the growth of knowledge, but shifted to the resistance against colonialism. Islamic civilization then started to experience a decline in the world history known as the age of the malaise of the ummah where contemporary position of the ummah in all fields, political (divided, disunited, military rule), economic (undeveloped, dependent on the West) and religio-cultural (westernized, alienated from Islam and its culture) (Al-Faruqi, 1982) and the age of crisis of Muslim mind where the scientific tradition started to vanish in the Muslim world (AbuSulayman, 1993).

John L. Esposito (1999: 45) observes that Europe colonialism in the Muslim world was a tremendous devastating and responsible for the backward of Islamic civilization as it has "replaced or transformed indigenous political, social, economic, legal, and educational institutions and explicitly as well as implicitly challenged Muslim faith and culture." Khurshid Ahmad (1994, p.52) likewise observes that Muslim confrontation to the West in the colonialism, especially in the $19^{\text {th }}$ century where almost the entire Muslim world under colonial rule, have resulted a 'fundamental' change in Muslim world, where the Muslim institutions of society, education, law, the judiciary, the economy and the military were changed, overwhelmed, restructured, replaced and modernized by Western ideas and institutions.

Western world that initially benefited from the advance civilization of Islam in their contact with Muslim world, on the other hand, started to gain their intellectual and cultural confidence and experienced a renaissance and started to re-construct and develop further all the sciences under their own worldview and epistemological foundations. Knowledge that they have gathered from Islamic world have been scrutinized critically in line with the spirit of enlightenment and modernism that detach the religious dogma and transcendental principles in sciences. In the $17^{\text {th }}$ centuries, and with its subsequent success in the description of natural phenomena, the sciences became separated from the theology and followed their own way in contrast to the sciences in the golden age of Islamic civilization. During the $19^{\text {th }}$ century, positivism and other schools of empiricism emerged and started to dominate academic circles and leaving the metaphysical doctrine behind. Interestingly, it was during this strong wave of positivism, modern science was transferred to the Islamic world and carried with it the underlying empiristic overtone, an outlook which 
separated sciences with from a theistic metaphysical framework. Science became a secular science where science is deemed to be not compatible with religion or is independent 0 it became dominant (Golshani, 2000: 2-3) .

In line with colonialism, this 'secularized' knowledge has been taught in the Muslim world massively and Muslims since they are already weak intellectually received and consumed this knowledge passively with a minimum effort to criticize them based on Islamic legacy. So, although Muslims have been leading intellectually when Islamic civilization dominated the world (especially in $7^{\text {th }}-11^{\text {th }}$ century), during this dark age in the history of Islam, they have become the follower of Western civilization and consumer of Western knowledge.

However, with the spirit to fade away the colonialism, the intention to establish an Islamic state that would apply Islamic principles in operation and the rise of a powerful Islamic movement in the late of $18^{\text {th }}$ and $19^{\text {th }}$ century which strive for serious attention to the application of the Islamic teachings in the practical affairs Muslim scholars have started to challenge the western concept of knowledge. With the advent of political independence in the Muslim world after World War II, contemporary Muslim scholars have been trying to challenge the western concept of sciences, reviving the Islamic intellectual heritage, re-discuss and establish sciences from within an Islamic framework. Some works that criticize western sciences from an Islamic perspective have been published as part of the effort to liberate from the Western alien paradigm that dominated intellectual tradition.

Among the scholars who contributed to the development of Islamic economics in $18^{\text {th }}$ and $19^{\text {th }}$ century (i.e. transitional period

7 Al-Attas (1993: 3) in the chapter 'The contemporary Western Christian Background' of his Islam and Secularism provided clear history of secularization experience of Western scientific tradition, started since the European enlightenment stretching from the $17^{\text {th }}$ to the $19^{\text {th }}$ centuries. Auguste Comte, the French philosopher, in the early half of the $19^{\text {th }}$ century described the rise of science and the overthrow of religion in the Western society as 'evolving' and 'developing' from the primitive to the modern stages where there is a transition from theology to science. Friedrich Nietzsche, a German philosopher, in his Zarathustra then declares God is dead. Western philosophers, poets, novelists at that time have anticipated and hailed it as preparing for an emancipated world with no God and no religion at all. The effort went on so far in the West, as to assert triumphantly, in their desire to keep in line with the contemporary events in the West, that secularization has its roots in biblical faith and is the fruit of the Gospel and, therefore, rather than oppose the secularizing process, Christianity must realistically welcome it as a processcongenial to its nature and purpose." 
towards a contemporary Islamic economics) such as Muhammad b. 'Abd al-Wahhab (1703-1792), Shah Wali Allah Dihlawi (1703-1762), Muhammad Murtadha al-Zabidi (d. 1791), 'Abd Aziz Dihlawi (17461824), Muhammad b. Ali al-Sanusi (1787-1859), Muhammad b. Ali alShawkani (1760- 1834), Uthman b. Fodio (1754-1817). The second generations are Abu al-Thana' al-Alusi (1802-1854), Ahmad Khan (1817-1898), Sayyid Jamal al-Din al-Afghani (1838-1897), Muhammad 'Abduh (1849-1905), Sayyid Muhammad Rashid Ridha (1865-1935), Muhammad lqbal (1877-1938), Mahmud Shukri al-Alusi (1857-1924), Jamal al-Din al-Qasimi (1866-1914), 'Abd al-'Aziz al-Tha'alibi (18751944), Muhammad al-Tahir b. 'Ashur (1879-1973), 'Abd al-Hamid b. badis (1889-1940), Tayyib al-'Uqbi (1888-1962), Muhammad al-Bahir al-Ibrahimi (1889-1965) and Muhammad Husayn Na'ini (1860-1936).

Their works are quite unique since they are facing the reality of Western advancement in science and technology and Islamic backwardness in science and technology. Their works in analyzing this reality as observed by Nafi (2004: 28) are more directed in three aspects: (1) re-exploration of the primary Islamic texts, the Qur'an and Sunnah, in their role in addressing the challenges facing the world of Islam, (2) re-evaluation the prevalent Islamic intellectual modes and their connections to the living conditions of Muslim, (3) defining the external, i.e., Western challenge, the nature of this challenge and the search for possible intellectual avenues for an Islamic-Western composite. Based on their efforts, those scholars are often called as the reformers of Islam or the pioneer of Islamic revival, since they are more concerned, in various degrees, with safeguarding Islamic tenets and identify in the face of destabilizing and unstoppable currents of modernization as with purifying religion from the shackles of traditions, whether they were local, sufi or unorthodox influences that impressed that the room for ijtihad is closed and thereby contributed to the decline of Islamic sciences (Rahnema, 1994 and Nafi, 2004, p.39). Muhammad Iqbal (1877-1938) one of the outstanding scholars in this phase delineated clearly that the "reconstruction of religious thought in Islam" is about the idea of return to the original spirit of Islam and at the same time to revolt against the finality of the schools and the spirit to revive the ijtihad (Bakar, 1997, p.68).

Rahnema (1994: 4) called this phase in intellectual Islamic history as the "ground-preparing phase" to "reinstate Islam as the 
principal coordinating mechanism of society". Their objectives are "reconstructing, reforming, reviving or synthesizing Islam in order to make it relevant to the needs, demands and predicaments of those whom they considered as the victims of modern civilization" (Rahnema, 1994: 6). In addition, the scholars of this period have felt that knowledge which is disseminated throughout the Muslim world was no longer has its strong roots to the knowledge developed by Muslim scholars when Islamic civilization dominated the world scientific tradition. Modern knowledge, its structure, classification, subject matter, content and methodology, has been infused by Western values. The scholars in this transitional period have started to challenge this western concept of knowledge and attempted to provide Islamic concept of knowledge.

Their works on economics was put to observe the decline of Muslim role in the world history and the initial challenge to the modern Western ideology of capitalism and socialism, their system of thought, material achievements, social relations and institutions, from an Islamic perspective. Again, although might be not comprehensive, due to their traditional background and rarely have a formal training in mainstream economics, their works was successful in articulating an Islamic ideology in a modern context and in cultivating the consciousness to the later generation on the shortcoming of west economic system and the need to develop our own Islamic economic system. Contemporary Islamic economics is essentially a continuation of these Islamic economics ideas in the transitional period.

\section{ISLAMIC ECONOMICS IN THE CONTEMPORARY TIMES}

The movement to revive Islam in contemporary time soon gained wide recognition in the late $19^{\text {th }}$ and $20^{\text {th }}$ century especially after the independence of Muslim countries from Western colonialism. The movement is ideological, intellectual as well as practical, which is often called as islah (reform) and tajdid (renewal) as opposed to taqlid (imitation) of the times and thinking of the past; al-sahwa alIslamiyyah (Islamic awakening) and al-nahda (Islamic renaissance, enlightenment) reflecting that the movement is a special response to the particular conditions prevailing in Muslim societies and at the same time to the conflicts and challenges of the modern world. 
It is a Muslim response to modernity ideologically as well as which is triggered by ideological, intellectual, and practical response to address the socio-economic reality of economic problems faced by the citizens of predominantly Muslim countries (e.g., of poverty and underdevelopment) and also to any 'wrong' practices (policies) of Capitalist or Socialist economic system inherited during colonialism in Muslim countries (e.g., interest-based banking system, assets and lands ownership, and etc) (Pfeifer, 1997, p.155) . $^{8}$.

The movement to revive Islamic thought in contemporary times, as in the above slogan, shows that it is part of the historical experience of renewal within Muslim societies over the centuries which essentially cannot be compartmentalized into certain period of time, circumstances or issues. John O. Voll (1991, p.23) observes that "it is part of both the contemporary experience when they deal with modern situations and of the continuity of concepts and ideas reflected in their heritage." The Islamic revival activists are searching for an identity that is truly Islamic, grounded in the best of the Muslim heritage while awake and responsive to the changes by the exigencies of modern living (Haddad, 1991, p.6) ${ }^{9}$.

In the $19^{\text {th }}$ and $20^{\text {th }}$ century concepts which had little relationship to the Islamic heritage such as nationalism, secularism, democracy, capitalism and socialism became vital parts of mainstream political and cultural discourses. The response by Muslims according to John O. Voll (1991) was evolved in two forms. (1) Early response was primarily made to adjust Islamic concepts to modern western perceptions rather than to reaffirm the Islamic heritage itself. The idea was aimed at creating a "modernized Islam". (2) The later form of Islamic revival however reverses this effort by affirming the Islamic discourse in a way that does not attempt to start with western form of modern ideas. A demarcation and disillusion with foreign ideologies, concepts and ideas has been shown clearly by the Muslims. The

8 The aims of this movement acoording to Pfeifer (1997: 155) is "to recapture the original moral and political authority of the anticolonial movements that gave rise to state capitalism". It is for this purpose, then Kuran (1995) claims that Islamic economics is originally emerged as a 'political response' with the sole purpose of establishing Islamic state wherein the Islamic economic principles would be applied.

9 This is in contrast to the claim of Kuran who said that contemporary Islamic revival is a fundamentalist movement that seeks to revive and implement of classical Islam in the laws and institutions. Islamic economics, he claimed is part of this movement. 
emphasis then has shifted from "modernizing" Islam to the "Islamization" of the modern experience. ${ }^{10}$

Islamic economics emerged in this intellectual revival tradition known as "Islamization of Knowledge" movement. It is an attempt to Islamize economics as a distinct Islamic science as well as a system. Specific Islamic science of economics did not emerge in the previous decades (i.e, the transitional phase), although the discussions were enormous. Islamic economics, with a distinct and systematic body of knowledge, is a modern creation that emerged in the twentieth century and its development can be distinguished into two phases; pre -1970 's and post - 1970's.

\subsection{Islamic Economics in Pre - 1970's}

Islamic economics in pre-1970's especially in 1940's-1960's was mainly contributed by the fuqaha i.e., scholars and writers with a background in Islamic sciences (Haneef, 1995; Kahf, 2003). Scholars such as Abu al-A'la al-Maududi ${ }^{11}$, Suharwi Muhammad Hifzur Rahman $^{12}$, Syaikh Mahmud Ahmad ${ }^{13}$, Sayyid Qutb $^{14}$, Yaqut al'Ashmawi ${ }^{15}$, Parwez Ghulam Ahmad' ${ }^{16}$, Muhammad Baqir al-Sadr ${ }^{17}$, and Ahmad Shalbi ${ }^{18}$ have continued the discussion of the works of Islamic economics in the transitional period and published specific book on 'Islamic economics'. Their works could be considered as initial works on Islamic economics in contemporary time. Their works are

10 In the nascent stage of the independent, the scholars as well as political leaders in the Muslim countries mostly choose to adopt the concepts as taught by the west which have been left to them during colonialism era. They were adopting capitalism or socialism in the case of economic system. Effort to infuse Islam in developing national ideology and state institutions (parliamentary systems of government, legal codes, education and economic system) received only less recognition (if not totally out of the system). (Esposito, 1991: 40)

11 Abu al-A'la al-Maududi, Insan ka Ma'ashi Mas'alah awr uska Islami Hall (1983), (Lahore: Islamic Publications Ltd., 18th ed. 1983; 1st ed., 1941), English translation. Economic Problem of Man and its Islamic Solution (Lahore: Islamic Publications Ltd., 2nd ed., 1970; 1st ed., 1947).

12 Seoharwi Muhammad Hifzur Rahman, Islam ka lqtisadi Nizam [Islamic Economic System], (Delhi,1942).

13 Syaikh Mahmud Ahmad, Economics of Islam: A Comparative Study (Lahore, 1947).

14 Sayyid Qutb, Al-'Adalah al-litma'iyyah fi al-Islam [Social Justice in Islam] (Al-Qahirah, 1948) and Ma'arakat al-Islam wa al-Ra'sumaliyyah[The Struggle Between Islam and Capitalism], (AlQahirah, 1951).

15 Yaqut al-'Ashmawi, al-Khutut al-kubra li al-nizam al-iqtisadi fi al-Islam [Major Principles of Islamic Economic System], (Al-Qahirah, 1959).

16 Parwez Ghulam Ahmad, Khuda aur sarmayadar [God and the Capitalist], (Lahore, 1967).

17 Muhammad Baqir al-Sadr, lqtisaduna [Our Economics], (Beirut, 1961).

18 Ahmad Shalbi, Al-Siyasah wa al-lqtisad fi al-Tafkir al-Islami [Politics and Economics in Islamic Thought], (Al-Qahirah, 1964). 
mainly looking economics in a general picture and not really systematic, more fighi oriented, less economic framework, much study was devoted to the construction of ideal worlds, by arguing the superiority of Islamic system and attacking Western socialist and capitalist system and very much influenced by the earlier transitional works on Islamic economics ${ }^{19}$.

The main contribution of the scholars in this period is in coining the term 'Islamic economics' and developing the philosophical foundation of Islamic economics. However, to study economics from an Islamic framework in a distinct dedicated works has not been done by previous scholars of transitional period. The period of $1940-1960$ is an initial phase of development of contemporary Islamic economics in the $20^{\text {th }}$ century.

Based on their works, Islamic economics gained wide recognition worldwide, and new generation of young Muslim western trained economists started to study economics from an Islamic perspective in systematic ways, with a distinct subject matter, body of knowledge, methodology and theory. And later on, especially in 1976 brought them to the first international conference on Islamic economics held in Makkah to officially declare the establishment of contemporary Islamic economics.

Although, many scholars believes that the term Islamic economics was initially coined in this phase. Scholars, however hold different views on who is the first in coining the term Islamic economics. Kuran (1995) argues that Islamic economics was initially coined by Abu al-A'la al-Maududi in 1941 by his book The Economic Problem of Man and Its Islamic Solution which was first published in Urdu in 1941 and then translated into English in 1975. Chapra (1996, p.194) on the other hand, in his comment to Kuran's article said that such impressive emerges if one only looks at some of the literature available in English, if we also look at the literature in Arabic we would have a different perspective on the launching and popularization of Islamic economics. Although he is not sure when the word al-iqtisad al-Islami or Islamic economics originated, he argues that it has roots deep in the historical writings of Qur'an commentators, jurist, historians, and social, political and moral philosophers. Likewise,

19 See for example Nienhaus (2000) and Wilson (1994). 
Yelcintas (1986) found that the books of Sayyid Manazir Ahsan Gilani of the Osmania University (India) and Seoharwi Muhammad Hifzur Rahman in Urdu language, titled Islamic Economics and Islamic Economic System was actually earlier written than Maududi's book. Their works then immediately followed by the inspiring works of Abul A'la al-Maududi in the subcontinent (in Urdu and English) and Hasan al-Banna (Arabic). Furthermore, Yelcintas, quoting Prof. Sabahuddin Zaim's survey argues that about $4 \%$ of the modern Turkish publications related to Islamic economics for the period ending 1975, came actually before 1950 reflecting that spirit to manage life in Islamic way was a worldwide phenomenon.

Wilson (2004) has tried to reconcile the differences by saying that although Maududi might not the first writer who coined the term Islamic economics and originated the contemporary discourse of Islamic economics in early 1940's, but Maududi is certainly the one who 'popularised' the term 'Islamic economics' and 'stimulate' the discussion in contemporary Muslim intellectual scene. This is because, unlike other writers, Maududi was a populist and able to attract growing number of followers amongst the young generation of economists especially in the Indian sub-continent. Maududi's work immediately gained wide recognition due to its Jama'at-i Islami movement who has many young intellectuals had undertaken postgraduate degrees in economics in the West and later on promote Maududi's legacy.

\subsection{Islamic Economics in Post - 1970's}

In the post 1970s era, Islamic economics' discussions have incorporated a more 'standard economic approach' even utilizing mathematics and econometric tools of analysis- to discuss both micro and macro level questions. Since then, a more distinctive discipline of Islamic economics has been firmly established ${ }^{20}$.

Contemporary Islamic economics is officially declared in 1976 when the first Islamic economics conference was convened in Makkah. Muslim scholars, from all over the world, at that time, had reached a

20 On the characteristics of contemporary Islamic economics in post-1970 see for example Haneef (1997). 
'consensus' on the need for a new economics based on the Islamic worldview and derived from legitimate Islamic sources of knowledge. This historical effort, according to Khurshid Ahmad (1981), is a watershed in the development of contemporary Muslim thinking on economics. The spirit was to transform the "Islamic teaching of economics" that have been done massively by Islamic scholars in pre1976 into a further systematic articulation of "Islamic economics" in post -1976 .

Serious theoretical works on Islamic economics begin to be published by the scholars who are educated by the Western economists such as Monzer Kahf (1978), ${ }^{21}$ M.A. Mannan (1980), ${ }^{22}$ S.N.H. Naqvi (1981), ${ }^{23}$ M. Umer Chapra (1985), ${ }^{24}$ and M. A. Choudhury $(1986)^{25}$ reflecting the shift of Islamic economics from a more fighi framework into a more standard economics framework. Their works, however, were written with a strong intellectual commitment to release economic studies from the conventional paradigm and establish a new economics based on a new framework that incorporates religious teachings into its theory and system. This new economics considers economics as an integrated and multidisciplinary science that is not value-neutral; a moral economy that pursues material well-being together with spiritual well-being; an economics where its epistemological foundations are based on divine revelation (wahy), the fact observation as well as intellectual reasoning ('aql).

The emergence of Islamic economics in this period is essentially in accordance with the rise of the twentieth century's Islamic resurgence worldwide which is actually a continuation of Islamic renewal tradition and has a root or historical continuity of the 'classical' Islam. Khursyid Ahmad (1994, p.51) for example sees that "Islamic resurgence is not merely a product of certain specific

21 Monzer Kahf. (1978). The Islamic Economy: Analytical Study of the Functioning of the Islamic Economic System. Plainfield, Indiana: The Muslim Students' Association of the United States and Canada.

22 M. A. Mannan. (1980). Islamic economics: Theory and practice. India: Idarah Adabiyat Delli.

23 Syed Nawab Haider Naqvi. (1981). Ethics and economics: An Islamic synthesis. United Kingdom: The Islamic Foundation.

24 M. Umer Chapra. (1985). Towards a Just Monetary System. Leicester, UK: the Islamic Foundation.

25 Masudul Alam Choudhury. (1986). Contributions to Islamic economic theory: A study in social economics. New York: St. Martin's Press. 
contemporary challenges, but one must see it in the context of as a historical continuity and the response of Muslims to the challenges of the contemporary world." The process of change, re-innovation, rethinking, reassertion, and reapplication is something that can be witnessed in all periods of Muslim history. He views that both perspectives should be dynamics and viewed in two dimensions; (1) the internal dimension, which is part of Muslim historical consciousness that makes Muslims reflect on their history in unique way and try to find future solutions that may stem from their background, and (2) the external climate of the contemporary political, intellectual, economic, structural, and technological situation that needs for immediate response ${ }^{26}$.

\section{THE CONTEMPORARY ISLAMIC ECONOMICS}

Now Islamic economics has reached forth decades of its development. Several questions might be asked. Along these years of development where Islamic economics is heading? Does Islamic economics make progress? Can we call now Islamic economics as a distinct science? What is the future direction of Islamic economics? There are three scenarios as well as critics on the trend and future direction on Islamic economic development.

First, Although, in 1960's - 1970's Islamic economics has entered the next phase of its development which is more modern (Haneef, 1995), but the figh al-mu'amalah approach in Islamic economics analysis is still apparent in contemporary times, especially if one read the literature in Arabic and in the field of Islamic banking and finance. Their approach to Islamic economics is based on figh framework and put the discipline of Islamic economics in a figh almua'amalah framework. Islamic economics in this regard is only concerned to establish 'shari'ah compliance' transactions in the case of Islamic banking and finance and in defining Shari'ah regulation, lawful or unlawful in consumption, production and distribution in the case of

26 Ahmad (1994) divided the historical development of Islamic resurgence as having three phases; (1) pre-colonial; (2) colonial; and (3) post-colonial. His classification is made based on the impact of colonialism in Muslim's world and civilization and Muslim response to it. Our division of Islamic economic development of having three phases; (1) the classical phase, (2) the transitional phase and (3) the contemporary phase is in accordance with Ahmad's division. Both shows that Islamic resurgence is not a recent phenomenon and should be viewed in the continuity of Islamic movement. 
Islamic economics. If this 'orthodox' view of Islamic economics, as put by Jomo (1993), is still dominant, the scope of Islamic economics discipline will be narrowed as it is concerned merely on the legal side of Islamic economics. In addition, Islamic economics as a discipline will not have an expanded scientific growth of knowledge and will have limited framework of study to Shari'ah (which has been defined narrowly as legal) or even narrower into only figh al-mu'amalah. Waleed A.J. Addas (2008, p.viii) in his preface to his book originated from his Ph.D dissertation after observing the nature and methodology of Islamic economics concludes that Islamic economics presently (after its 30 years development) is no more than the result of applying the Islamic rules and injunctions, i.e. Islamic figh, to secular economics. Islamic economics is not yet a discipline that replaces secular economics.

Second, while early writings in contemporary Islamic economics of the 1970's and 1980's did pay attention to some aspects of economic theory and philosophy, the 1990s clearly saw a shift of emphasis to more commercial areas such as Islamic banking and finance. Philosophical studies and approaches were almost extinct in most of Islamic economics writings. There exists lack of philosophical studies in Islamic economics discourse that would develop distinct conceptual framework of Islamic economics and philosophical foundations of the discipline. As a result, there exists some confusion in the discussion of what Islamic Economics consists of as many writers limit Islamic economics studies to the study of its principles of banking and finance and others on figh al-mu'amalah (Islamic transactions). In addition, larger area of Islamic economics, both microeconomics and macroeconomics become neglected and not properly explored as more resources, thinking and funding, have been mainly put in the sector of Islamic banking and finance. At the end, if Islamic economists maintain this scenario Islamic economic discourse then we are unable to promote a coherent school or schools of economic thought. The larger significance and the future of Islamic economics becomes narrowed and blurred, resulting in a limited growth of the scientific framework of Islamic economic thought (Nasr 1987; Sardar, 1988, pp.198-217).

Third, Islamic economics is often claimed by its proponents to be an Islamic alternative approach to conventional mainstream economics 
which impressed that Islamic economics has different views on most of the notion of economics. In order to proof it, Islamic economics thus should initially attack and propose alternative of the core of neoclassical economics theoretical foundations. This means it has to make an Islamic view as point of departure in economic theorizing and analyzing rather than from a neo-classical paradigm and then try to Islamize it. But, the current scenario shows a different thing. Islamic economics heavily depends on conventional economics especially neoclassical paradigm in order to develop Islamic economics. Most of theories used in empirical studies are conventional in nature and the findings which are done in the case of Islamic society (system) usually tend to confirm the existing conventional theories than to reject and offer alternative theories. Consequently, as Syed Farid Alatas (2006) observes, Islamic economics as empirical theory has not done much. It remains within the fold of Western modernist discourse in terms of theoretical concerns and methodology and therefore failed to offer an alternative princples to modernization and dependency to the dominant paradigm"27. Chapra (2000, p.35) also notes that "its theoretical core has also thus far been unable to come out the straitjacket of conventional economics, which takes into account primarily the economic variables that are measurable and generally avoids a discussion of the complex historical interplay of moral, psychological, economic social and political factors. In the word of Nasr (1991, p.388) islamic economcis has thus "failed to escape the centripetal pull of Western economic thought, and has in may regards been caught in the intellectual web of the very system it set out to replace."

Forth, in line with third scenario and critique, Islamic economics emerged in contemporary time as the result of intellectual movement among the Muslim scholars to Islamize knowledge or dewesternize knowledge and infuse with Islamic principles. Islamic economists in this case attempt to re-evaluate contemporary economic theories which are bias and have been infused by Western values, from an

27 Farid Alatas (2006) then continues criticizing Islamic economics as an empirical theory with "neo-classical guise" that "merely substituted Islamic terms for neo-classical ones, retaining the latter's assumptions, procedures and modes of analysis. As such, it has failed to engage in the analysis and critique of a highly unequal world economic order in which the gaps are ever widening." 
Islamic perspective and at the same time attempt to formulate economic theories based on Islamic sources of knowledge.

Since the late 1970's and 1980's there is awakening consciousness among Muslim intellectuals to revive Islamic perspective in various kind of knowledge (al-Faruqi, 1982; Haneef, 2005). Islamization of knowledge as an intellectual movement in modern history of Islam is done massively by Muslim scholars who do not merely come from traditional-religious background, but come from modern-western educated background but able to speak to the growing proportion of Muslim societies and modern-western educated background but not willing to become secularists (Esposito and Voll, 2001, p.20). According to this scenario, Islamic economics is essentially a product of creative synthesis of modern economy and Islamic heritage. In other word, while the roots of Islamic principles is well maintained in developing discipline, the advance development of economic analysis of conventional economics is well welcomed.

But again, the critics currently is that in doing Islamization of economics, Islamic economists often being trapped into conventional paradigm and hence doing a westernization of Islam by fitting Islamic teaching into neo-classical outfit. The 'integration' program of modern economics and Islamic teachings in Islamization of knowledge is often led into 'replication' of conventional theory into an Islamic mould in the process of theory appraisal. The integrative direction moves in a reverse direction, i.e., instead of converting conventional paradigm into Islamic, Islamic economics become trapped into that dominant paradigm. This probably true if we see the current development in Islamic economics promoted by a 'mainstream school' in Islamic economics discourse which is modeled along neoclassical lines, working almost within the boundaries of neoclassical theory, with some adjustments to incorporate teachings/norms/values that reflected certain requirements of Islam which is not necessarily to be 'Islamic' (Haneef, 2005). Choudhury (1999, p.1) also observes that:

In recent years when Muslim scholars wrote on Islamic economics, they had to turn to mainstream economic theories and clothe these up with a palliative of Islamic values. But no new challenge was posed on the epistemological beginnings of a new field of analytical 
and scientific study. There was no demand from the Muslim scholars to well-define a distinctive field of Islamic economics. The Muslim scholars thus approached the study of Islamic values in neoclassical economic models of behaviour and resource allocation without questioning either the value-orientation of neoclassicalism or the possibility of treating Islamic values in such otherwise value-free models of economic behaviour, pricing and allocation.

The 'Western criteria' for building and evaluating economic theories is still used in developing Islamic economics discipline. Islamic economics, by this scenario/trend, instead of becoming a distinct discipline that could analyze economics using its own distinct philosophy, concept, framework and method of analysis as intended by the project of Islamization of knowledge, it becomes a subdiscipline of conventional economics that heavily depends on all aspect of the discipline. Unless there is a new spirit to keep Islamic economics on its right track of proposing and attempting to develop a 'new' economics, we hardly find it will be able to progress in the future (Furqani and Haneef, 2013).

\section{CONCLUSION AND THE WAY FORWARD}

Muslim scholars have put efforts to develop this new economics based on Islamic principles. The spirit was to transform Islamic teachings into a system of thought and then to implement in it in economic realities. Contemporary Islamic economics, although, claimed to be a modern creation of Muslim's twentieth century intellectual enterprise its roots is dated back to the $7^{\text {th }}-12^{\text {th }}$ century in the works of classical Muslim scholars when they dominated and enlightened the world scientific tradition. Many progresses have been achieved so far to make Islamic economics study become more advance, systematic, and modern. However, as the above evaluation of the future of Islamic economics, much efforts and times are still needed to accomplish the task of creating a distinct discipline of Islamic economics with the criteria of a clear 'subject matter', an 
organized 'body of knowledge', a distinct 'epistemological/ methodological foundation' and new 'theories' in economics.

The future direction of Islamic economics as a distinct discipline as explained in above scenarios give us clear message that Islamic economics in order to sustain itself and to evolve to a position of greater strength, has to persistently develop its own foundations and body of knowledge by using its own epistemological framework to reach a discipline status (i.e. an 'ilm of Islamic economics) and to determine its future direction in order to ensure a sustainable growth of knowledge. The program of dewesternization of knowledge as well as Islamization of knowledge in developing Islamic economics should be done by the spirit of putting Islamic economics into its 'proper' outfit and not into a conventional of capitalism, socialism, or other outfit. And this will require a qualitative renewal of its philosophical base that constitutes the elements of philosophy of sciences of the ontology (of what is the nature of Islamic economics in Islam), epistemology (of how to develop Islamic economics using Islamic sources of knowledge) and axiology (for what Islamic economics is in terms of its application and direction). Without our distinct and solid epistemological foundations that are projected from an Islamic worldview or vision that represents Islamic approach it is difficult to create and develop a 'distinct' Islamic economics as conceived by Islam. 


\section{REFERENCES}

Abu Sulayman, Abdul Hamid, A. (1993). Crisis in the Muslim Mind. Herndon, Virginia, USA: IIIT.

Addas, Waleed A. J. (2008). Methodology of Economics: Secular vs Islamic. Kuala Lumpur: IIUM Press.

Ahmad, Khursyid. (1994). Islamic Resurgance: Challenges, directions, and Future Perspective. In Ibrahim M. Abu Rabi' (Ed.), Islamic Resurgance: Challenges, Directions and Future Perspectives, A Roundtable With Khurshid Ahmad (pp. 49-66). Florida, USA: WISE.

Ahmad, Khurshid. (1981). Introduction. In M. N. Siddiqi, Muslim Economic Thinking: A Survey of Contemporary Literature. Leicester, United Kingdom: The Islamic Foundation.

Alatas, Syed Farid. (2006). Islam and the Science of Economics. In Ibrahim M. Abu Rabi' (Ed.), The Blackwell Companion to Contemporary Islamic Thought (pp. 587-606), USA: Blackwell Publishing.

Bakar, Osman. (1997). Islam and Civilizational Dialogue: The Quest for A Truly Universal Civilization. Kuala Lumpur: University Malaya Press.

Behdad, Sohrab. (2005). Book reviews of S. M. Ghazanfar (Ed.), Medieval Islamic Economic Thought: Filling the "Great Gap" in European Economics. (London: RoutledgeCurzon, 2003.). Economic Development and Cultural Change, (pp. 280-283).

Chapra, M. Umer. (2000b). Is It Necessary to Have Islamic Economics. Journal of Socio-Economics, 29, 21-37.

(1996). Comments on Islamic Economics and the Islamic subeconomy. Journal of Economic Perspective, 10(3), 193-195.

Choudhury, Masudul Alam. (1999). Editorial: Islamic Economics and Islamic Political Economy. Managerial Finance, 25(5), 1.

(1986). Contributions to Islamic Economic Theory:

A Study in Social Economics. New York: St. Martin's Press.

Esposito, John L. (1999). The Islamic Threat: Myth or Reality (3rd ed).

Oxford: Oxford University Press. 
Esposito, John L and Voll, John O. (2001). Makers of Contemporary Islam. Oxford: Oxford Univeristy Press.

Al-Faruqi, Ismail Raji. (1982). Islamization of Knowledge: The Problem, Principle and the Workplan. Herndon: International Institute of Islamic Thought.

Ghazanfar, S. M. (2003). Medieval Islamic Economic Thought: Filling The "Great Gap" in European Economics. London: Routledge Curzon.

Haneef, Mohamed Aslam Mohamed. (2005). A Critical Survey of Islamization of Knowledge. Kuala Lumpur: Research Centre, IIUM.

Haneef, Mohamed Aslam Mohamed. (1995). Contemporary Islamic Economic Thought: A Selected Comparative Analysis. Kuala Lumpr: Ikraq.

Islahi, Abdul Azim. (2004). Contribution of Muslim Scholars to Economic Thought and Analysis (11-905 A.H./635-1500 A.D.). Jeddah: Islamic Economics Research Centre King Abdul Azis University.

Jomo, K.S. (1993). Introduction. In Jomo K.S (Ed.), Islamic Economic Alternatives: Critical Perspectives and New Directions (pp. 1-7). Kuala Lumpur: Ikraq.

Kahf, Monzer. (2003). Islamic Economics: Notes on Definition and Methodology. Review of Islamic Economics, 13, 23-47.

Kuran, Timur. (1995). Islamic Economics and the Islamic Subeconomy. Journal of Economic Perspective, 9(4), 155-173.

Mannan, M. A. (1980). Islamic Economics: Theory and Practice. India: Idarah Adabiyat Delli.

Nafi, Basheer M. (2004). The Rise of Islamic Reformist Thought and Its Challenge to Traditional Islam. In SuhaTaji-Farouki and Basheer M. Nafi (Eds.), Islamic Thougth in the Twentieth Century (pp. 28-60). London: I.B. Tauris.

Nasr, Seyyed Vali Reza. (1991). Islamization of Knowledge: A Critical Overview. Islamic Studies, Autumn, 387-400.

Nasr, Seyyed Vali Reza. (1987). Towards a Philosophy of Islamic Economics. The Muslim World, LXXVII, 175-196.

Naqvi, Syed Nawab Haider. (1981). Ethics and Economics: An Islamic Synthesis. United Kingdom: The Islamic Foundation. 
Nienhaus, Volker. (1982). Literature on Islamic Economics in English and German. Germany: Koin (Al-Kitab Verlag).

Orman, Sabri. (1997). Sources of the History of Islamic Economic Thought. Al-Shajarah, 2(2), 21-62.

Pfeifer, Karen. (1997). Is There An Islamic Economics?. In Joel Beinin and Joe Stork (Eds.), Political Islam: Essays from Middle East Report, London: I.B. Tauris.

Rahnema, Ali. (1994). Introduction. In Ali Rahnema (Ed.), Pioneers of Islamic Revival (pp. 1-10), London: Zed Books Ltd.

Sardar, Ziauddin. (1988). Islamic Futures: The Shape of Ideas to Come. Kuala Lumpur: Pelanduk Publication.

Siddiqi, Muhammad Nejatullah. (1981). Muslim Economic Thinking: A Survey of Contemporary Literature. Leicester, United Kingdom: The Islamic Foundation.

Wilson, Rodney. (2004). The Development of Islamic Economics: Theory and Practice. In Suha Taji-Farouki and Basheer M. Nafi (Eds.), Islamic Thought in The Twentieth Century (pp. 195-222), London: I.B. Tauris. 